\title{
DISTRIBUSI SPASIAL KLOROFIL- a DI PERAIRAN PANTAI KABUPATEN TULUNGAGUNG JAWA TIMUR MENGGUNAKAN TEKNOLOGI PENGINDERAAN JAUH
}

\author{
Umi Zakiyaho,", Gema Ayu Rohania, Arief Darmawan ${ }^{\mathrm{a}}$ \\ ${ }^{a}$ Fakultas Perikanan dan Ilmu Kelautan Universitas Brawijaya \\ Jl. Veteran Malang, Jawa Timur, Indonesia
}

*Koresponden penulis : umi.zakiyah@gmail.com

\begin{abstract}
Abstrak
Wilayah pesisir merupakan daerah yang sangat intensif dimanfaatkan untuk kegiatan dan aktifitas manusia seperti transportasi, agribisnis, pariwisata, serta kawasan permukiman. Tujuan dari penelitian ini yaitu untuk mengetahui sebaran spasial kandungan klorofil-a di perairan Kabupaten Tulungagung dengan memanfaatkan teknologi penginderaan jauh. Selain itu juga untuk memvalidasi data citra dengan data in situ. Secara in situ dilakukan pengukuran klorofil-a, dan pengukuran kualitas air seperti: suhu, kecerahan, $\mathrm{pH}$, nitrat dan fosfat. Kemudian dengan metode penginderaan jauh, citra Landsat 8 diekstraksi untuk mendapatkan sebaran spasial klorofil-a menggunakan Jaelani $\log (\mathrm{Chl}-\mathrm{a})=-0,9889 \times\left(\mathrm{Rrs}_{4} / \mathrm{Rrs}_{5}\right)+0,3619$. Metode yang digunakan dalam Penelitian ini adalah metode deskriptif dan dilakukan pada 10 titik stasiun secara purposiv. Hasil penelitian analisis sebaran spasial Klorofil-a dengan penginderaan jauh di Kabupaten Tulungagung, Jawa Timur diperoleh nilai sebaran klorofil-a in situ berkisar 1,62-3,69 mg/m $\mathrm{m}^{3}$, nilai klorofil-a citra berkisar 0,86$1,31 \mathrm{mg} / \mathrm{m}^{3}$ dengan nilai akurasi untuk klorofil-a sebesar $46 \%$. Pola sebaran klorofil berpusat di stasiun yang terdapat aktifitas pelabuhan dan area keramba jaring apung dan menurun di area sekitar nya. Didapatkan nilai kualitas air yakni suhu berkisar $29,22-29,83^{\circ} \mathrm{C}$, kecerahan berkisar 40,5-53 cm, pH didapatkan nilai 7,92-8,07 dari semua stasiun, nitrat berkisar 0,009-0,052 mg/l dan fosfat berkisar 0,017-0,342 mg/l yang masih dalam batas optimal untuk perairan.Dapat disimpulkan bahwa aktivitas manusia seperti pelabuhan atau keramba jarring apung memberikan dampak signifikan terhadap kualitas lingkungan.
\end{abstract}

Kata Kunci : pesisir, sebaran spasial, , klorofil-a, penginderaan jauh, dampak anthropogenik

\begin{abstract}
Tulungagung coastal areas considered as intensive areas used for human activities such as transportation, industrial estates, agribusiness and tourism, as well as residential areas. These activities will certainly effect the aquatic fertility that can be indicated by chlorophyll-a based phytoplankton biomass. Therefore, the purpose of this research are to study the spatial distribution of chlorophyll-a using remote sensing technology. As well as the conduct validation of the satellites data with in situ. During the survey, in situ data were collected such as chlorophyll-a, and water quality measurement such as: temperature, brightness, pH, nitrate and phosphate by using spectrophotometer. Furthermore, the satellites data of chlorophyll-a concentration were extracted from Landsat 8 imagery and processed with Jaelani algorithm: Log $($ Chl-a) = $0.9889 \times\left(\operatorname{Rrs}_{4} / \operatorname{Rrs}_{5}\right)+0.3619$ algorithms. This research used descriptive method and were carried out at 10 stationary point on purpose. The result of this research showed that the value of chlorophyll-a on in situ value ranges between 1.62 to $3.69 \mathrm{mg} / \mathrm{m}^{3}$, the value of chlorophyll-a image value ranges between 0.86 to $1.31 \mathrm{mg} / \mathrm{m}^{3}$ with an accuracy value of $46 \%$ for chlorophyll-a. The distribution pattern showed that the highest were located at the harbor and area with fish floating cage and decrease to the surrounding areas. Water quality were obtained the temperatures ranges between $29.22-29.83^{\circ} \mathrm{C}$, the brightness value ranges between 40.5 to $53 \mathrm{~cm}$, the $\mathrm{pH}$ value ranges between 7.92-8.07, nitrate value ranges between 0.009-0.052 $\mathrm{mg}$ $/ L$ and phosphate value ranges between 0.017- $0.342 \mathrm{mg} / \mathrm{L}$. As conclusions, all the parameters values calculated were still I n optimum ranged. It can be concluded that human activities such as harbor or fish floating cage gave a significant impact to the surrounding areas.
\end{abstract}

Keywords: Coastal areas, spatial distribution, chlorophyll-a, remote sensing technology, human impact 


\section{PENDAHULUAN}

Pesisir merupakan tempat bertemunya daratan dan lautan [4]. Wilayah pesisir merupakan daerah yang sangat intensif dimanfaatkan untuk kegiatan dan aktifitas manusia [11]. Wilayah pesisir dimanfaatkan unuk tempat mencari makan, namun selain itu juga dimanfaatkan untuk transportasi dan pelabuhan, kawasan industri, agribisnis dan agroindustri, rekreasi dan pariwisata, serta kawasan permukiman dan tempat pembuangan limbah [8]. Pemanfaatan wilayah pesisir yang berkembang secara intensif mengakibatkan terlampauinya daya dukung atau kapasitas berkelanjutan dari ekosistem pesisir, seperti pencemaran [7]. Dampak pencemaran tidak hanya membahayakan biota laut, terutama fitoplankton yang berperan penting dalam produktivitas perairannya. Selain itu berdampak pada kualitas air lingkungan laut [1].

Fitoplankton merupakan indikator perubahan lingkungan dan merupakan produsen primer di perairan [10]. Keberadaan fitoplankton di perairan dapat dideteksi dari kandungan klorofil-a nya karena dibutuhkan oleh fitoplankton untuk bertahan hidup dan berfotosintesis [12]. Pigmen - pigmen fitoplankton (khususnya klorofil-a) merupakan komponen utama yang mempengaruhi sifat optik/biooptik air laut [16]. Oleh karena itu, metode penginderaan jauh dapat digunakan dalam pendugaan konsentrasi klorofil-a di perairan. Pengukuran klorofil-a dapat dilakukan dengan dua cara yaitu konvensional dan menggunakan teknologi penginderaan jauh. Pemanfaatan teknologi penginderaan tidak membutuhkan waktu yang lama dan biaya yang relatif rendah [10]. Metode pengukuran lapangan (in situ ) dilakukan guna mendapatkan data untuk verifikasi hasil yang diperoleh dengan metode penginderaan jauh.

Kabupaten Tulungagung kecamatan Besuki khususnya Pantai Popoh merupakan salah satu pantai yang terdapat banyak aktifitas manusia dan juga merupakan muara dari Sungai Niyam yang dapat menyebabkan perubahan kualitas perairan. Berdasarkan latar belakang tersebut, diperlukan adanya usaha untuk memantau persebaran secara spasial Klorofil-a di Perairan Pantai Kabupaten Tulungagung mengingat pentingnya potensi yang ada. Salah satu pemantauan yang dapat dilakukan adalah menggunakan data satelit penginderaan jauh.

Berdasarkan latar belakang dan permasalahan diatas maka penelitian ini dilakukan untuk menganalisis sebaran secara spasial klorofil-a di perairan Kabupaten Tulungagung yang pada akhirnya akan dapat menjelaskan pengaruh aktivitas manusia yang berada disekitar lingkungan perairan ini terhadap kesuburan dan produktivitas perairannya

\section{METODE PENELITIAN}

Penelitian ini dilaksanakan di Pesisir Kecamatan Besuki dan Tanggung Gunung Kabupaten Tulungagung Jawa Timur pada bulan April 2018 pada 10 stasiun yang ditentukan secara purposive. Pengambilan data citra dilakukan dengan mendownload citra satelit Landsat 8 OLI yang mewakili dari 10 titik sampling di sepanjang perairan pantai yang diteliti dan diproses dengan menggunakan software QGIS.

Alat yang digunakan dalam penelitian ini antara lain AAQ, secchi disk, GPS, cool box, pompa vacuum, spektrofotometer, cawan porselen, hot plate, Erlenmeyer, kertas saring, botol, water sampler, laptop 64-bit, Software QGIS dan Software Google Earth. Bahan yang digunakan pada penelitian ini adalah Aquades, asam fenol disulfonik, $\mathrm{NH}_{4} \mathrm{OH}$, Amonium molybdat, es batu, $\mathrm{SnCl}_{2}$, air laut, Landsat 8 dan peta rupa bumi.

Metode yang digunakan dalam penelitian ini adalah metode deskriptif. metode deskriptif adalah metode penelitian yang digunakan untuk menemukan pengetahuan yang seluas-luasnya terhadap objek penelitian pada suatu masa tertentu [7]. 


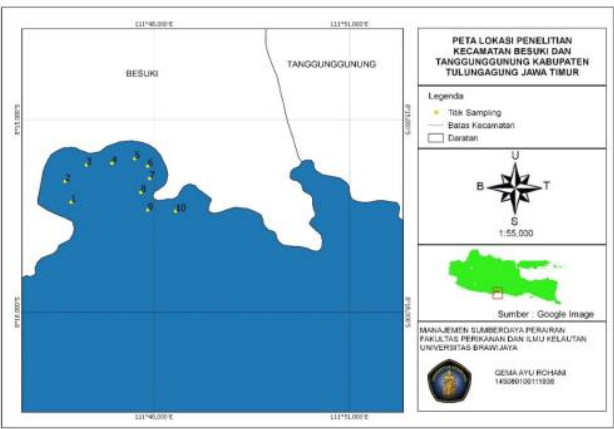

Gambar 1. Peta Lokasi Penelitian

Tabel 1. Lokasi Stasiun Pengambilan Sampel

\begin{tabular}{cl}
\hline Stasiun & \multicolumn{1}{c}{ Landuse } \\
\hline 1 & Pantai Gemmah \\
2 & Pantai Gemmah \\
3 & Tambak \\
4 & Aliran sungai \\
5 & Pemukiman \\
6 & Pelabuhan Pantai Popoh \\
7 & Pelabuhan Pantai Popoh \\
8 & Keramba Jaring Apung \\
9 & Keramba Jaring Apung \\
10 & Pantai Coro \\
\hline
\end{tabular}

Tahapan penelitian pertama dilakukan yakni melakukan survey di lokasi penelitian Pengunduhan data citra satelit sebagai pengolahan data spasial sebaran Klorofil-a, dan pengambilan stasiun air di lapang untuk diamati tiga parameternya, yaitu parameter fisika, kimia dan biologi yang berkaitan dengan Klorofil-a. Kemudian menganalisis keakuratan dari data spasial dan data lapang.

Pengambilan stasiun dilakukan pada sepuluh titik yang telah ditentukan secara sistematik di daerah kecamatan pesisir Besuki dan Tanggung Gunung Kabupaten Tulungagung Jawa Timur dapat di lihat pada Gambar 1. Stasiun pengambilan stasiun dalam penelitian ini berfungsi untuk mewakili beberapa titik yang menggambarkan keadaan lapang atau tempat penelitian yang ditinjau dari pengaruh kegiatan yang ada disekitar titik pengambilan stasiun, sehingga data yang didapatkan merata. Penentuan lokasi pengambilan data berada pada beberapa stasiun dapat dilihat pada Tabel 1 .

\section{Pengolahan Data}

Pengolahan data in situ pada penelitian ini meliputi pengukuran parameter kualitas air yaitu parameter biologi, fisika, dan kimia. Parameter biologi meliputi klorofil-a. Parameter fisika meliputi suhu dan kecerahan. Parameter kimia meliputi, Nitrat dan Fosfat. Proses awal yang dilakukan dalam pengolahan data satelit adalah pengunduhan citra satelit Landsat 8 OLI.

\section{Koreksi Citra}

Koreksi geometrik yakni koreksi untuk menyesuaikan posisi pada citra dengan posisi pada peta. Selanjutnya dilakukan koreksi radiometrik untuk merubah nilai digital number suatu objek menjadi nilai refletansi objek tersebut. Terakhir adalah koreksi atmosferik dilakukan untuk menghilangkan path radiance (noise angkasa).

\section{Masking Layer}

Masking Layer adalah proses pemisahan suatu objek tertentu (yang diinginkan) dengan objek lain (yang tidak diinginkan) berdasarkan nilai spektral pada data digital.

\section{Algoritma}

Algoritma merupakan formula yang digunakan pada tahap analisis untuk mengetahui kondisi klorofil-a dan yang digunakan untuk analisis klorofil-a adalah algoritma Jaelani.

Persamaan matematis algoritma klorofil-a :

Chl-a $\left((\mathrm{mg} / \mathrm{m} 3)=-0,9889 x\left(\frac{R+s 4}{R+s 5}\right)+0,3619\right.$ 


\section{HASIL DAN PEMBAHASAN}

\section{Analisis Klorofil-a Berdasarkan Data In Situ}

Nilai klorofil-a berkisar antara 1,62 $\mathrm{mg} / \mathrm{m}^{3}-3,69 \mathrm{mg} / \mathrm{m}^{3}$. Konsentrasi klorofil-a tertinggi berada titik stasiun 8 yang merupakan area atau stasiun yang terdapat keramba budidaya lobster. Sedangkan titik stasiun terendah yakni titik stasiun 2 yang merupakan lokasi pesisir yang dekat dengan pantai tempat wisata. Adapun sebaran spasial klorofil-a. Berdasarkan data in situ tersaji pada Gambar 2.

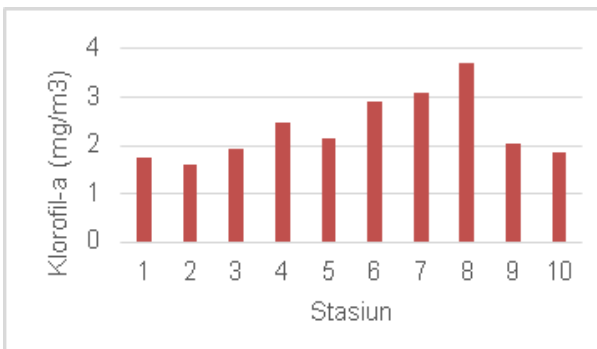

Gambar 2. Tabel Hasil Analisis Klorofil-a in-situ

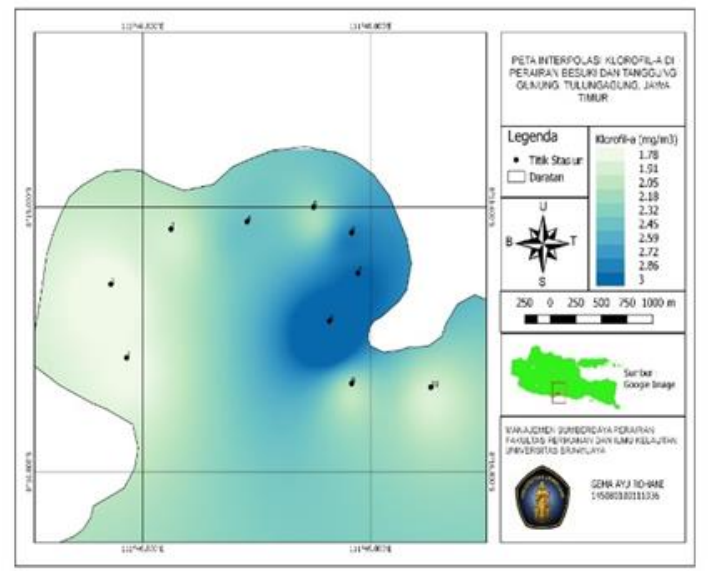

Gambar 3. Peta Sebaran Klorofil-a In Situ

Berdasarkan analisis konsentrasi klorofila tertinggi berada di bagian pantai yang dekat dengan pelabuhan dan keramba jaring apung (stasiun 8) dan berangsur menurun di daerah pantai Gemmah dan pantai Coro (stasiun 9 dan 10) atau menuju luar teluk. Tinggi (menuju stasiun 1) dan rendahnya sebaran klorofil-a disebabkan karena pengaruh masukan nutrien (amonia, nitrat, nitrit, dan ortofosfat) yang berbeda dari lingkungan yang berbeda di setiap titiak sampling [11]. Selain itu, faktor cahaya matahari, pasang surut, waktu tinggal air, dan pemangsaan juga sangat memengaruhi tingkat kesuburan perairan [3].

\section{Analisis Klorofil-a Berdasarkan Data Citra}

Klorofil-a tertinggi terdapat pada titik stasiun 7 yakni $1,31 \mathrm{mg} / \mathrm{m}^{3}$ yang merupakan area pelabuhan dan nilai terendah adalah titik stasiun 10 yakni $0,86 \mathrm{mg} / \mathrm{m}^{3}$ merupakan lokasi pesisir yang dekat dengan pantai Coro. Berdasarkan data Citra Sebaran klorofil-a tersaji pada Gambar 4.

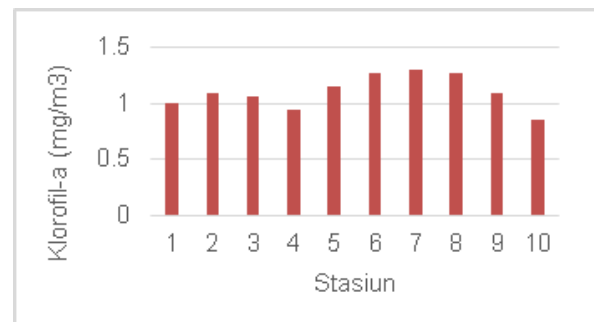

Gambar 4. Sebaran nilai Klorofil-a dari data citra berdasarkan stasiun

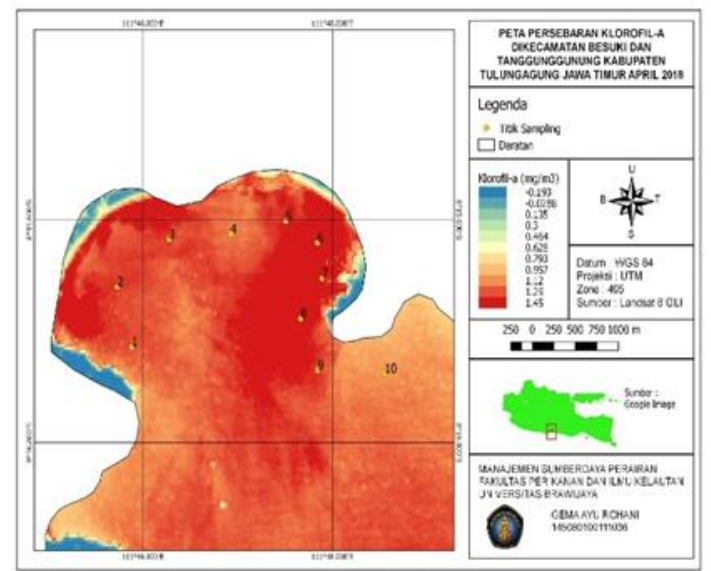

Gambar 5. Peta Sebaran Klorofil-a dari data citra

Berdasarkan analisis Algoritma Jaelani konsentrasi klorofil-a memiliki nilai lebih rendah dibandingkan dengan hasil pengukuran data in situ. Hal ini disebabkan adanya gangguan cuaca pada saat pengambilan data citra sehingga diasumsikan terjadi perubahan nilai yang didapatkan. Berdasarkan teori meskipun data citra dan data in situ diambil pada waktu yang sama prosentasi perbedaan dapat mencapai maksimal $20 \%$ [9], Polhal ini terutama karena adanya perbedaan metode 
pengambilan data. Konsentrasi nilai citra memiliki kecenderungan pola yang sama dengan konsentrasi nilai di lapangan, akan tetapi terdapat beberapa titik dengan perbedaan yang signifikan. Perbedaan nilai in situ dengan nilai dapat disebabkan oleh perbedaan waktu pengambilan data in situ dengan waktu perekaman citra dan kondisi citra yang mendapat pengaruh dari tutupan kabut tipis (haze) [12].

\section{Uji Akurasi Klorofil-a In Situ dan Citra}

Nilai akurasi Klorofil-a didapatkan yakni sebesar $46 \%$. Hasil akurasi klorofil-a citra dengan in situ yang didapatkan masih dibawah nilai ketelitian yang dikatakan baik. Hal ini disebabkan oleh waktu perekaman citra dan waktu pengambilan data lapang berbeda.

Secara keseluruhan kemampuan instrumen penelitian dalam hal ini citra Landsat 8 untuk Klorofil-a lebih baik apabila pengambilan citra dengan pengambilan data lapang pada waktu yang sama untuk melihat bahwa data yang didapat dari citra sudah sesuai dengan keadaan lapang.

\section{Parameter Kualitas Air}

Suhu

Suhu air didapatkan berkisar antara $29,22^{\circ} \mathrm{C}-29,83^{\circ} \mathrm{C}$. Sehingga dapat disimpulkan bahwa nilai suhu perairan termasuk nilai suhu yang optimal. Suhu optimal untuk pertumbuhan plankton di lautan yaitu antara $20-30^{\circ} \mathrm{C}[3]$.

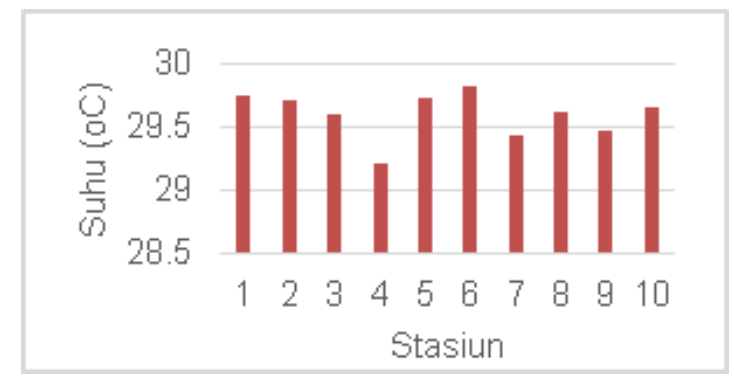

Gambar 6. Grafik Sebaran Suhu di Lokasi Penelitian

\section{Kecerahan}

Nilai Kecerahan berkisar antara 40,5-53 $\mathrm{cm}$. Sebaran nilai ini tergolong rendah. Rendahnya kecerahan dapat disebabkan oleh adanya proses sedimentasi perairan yang berasal dari aktifitas-aktifitas yang tinggi di perairan seperti kegiatan transportasi, pelabuhan dan pemukiman. Kecerahan merupakan faktor penentu daya penetrasi cahaya matahari yang masuk ke perairan [15].

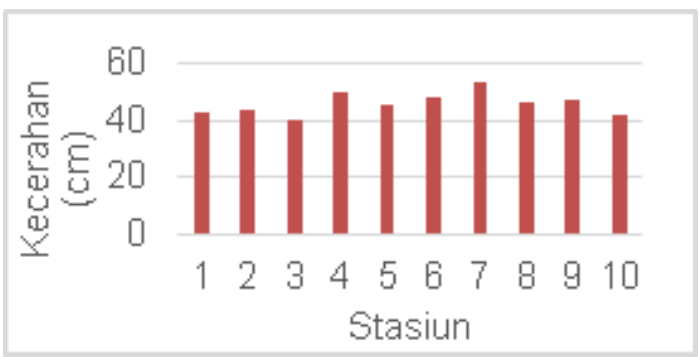

Gambar 7. Grafik Sebaran Kecerahan di Lokasi Penelitian

$p H$

$\mathrm{pH}$ air yang diperoleh dalam penelitian yakni berkisar antara 7,92-8,07. Nilai $\mathrm{pH}$ tersebut masih termasuk dalam batas ideal suatu perairan. Hal ini sesuai dengan pernyataan [4], bahwa batasan $\mathrm{pH}$ yang ideal bagi biota laut nilainya berkisar antara 6,58,5 .

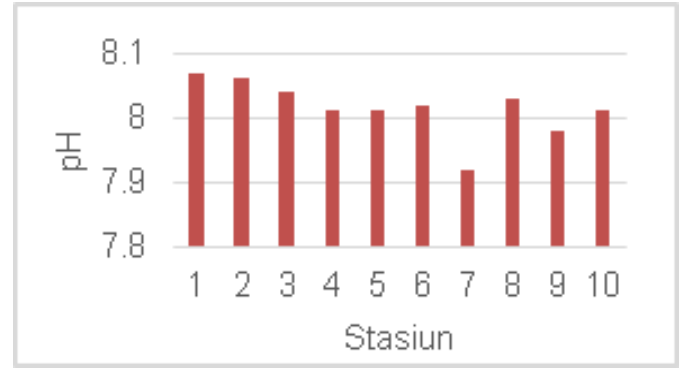

Gambar 8. Grafik Sebaran pH di Lokasi Penelitian

$\operatorname{Nitrat}\left(\mathrm{NO}_{3}\right)$

Konsentrasi nitrat yang diperoleh berkisar antara $0,009 \mathrm{mg} / \mathrm{l}-0,052 \mathrm{mg} / \mathrm{l}$. Nilai nitrat Nitrogen berperan dalam pertumbuhan fitoplankton atau alga yang biasa digunakan 
sebagai indikator kualitas air dan tingkat kesuburan suatu perairan [5].

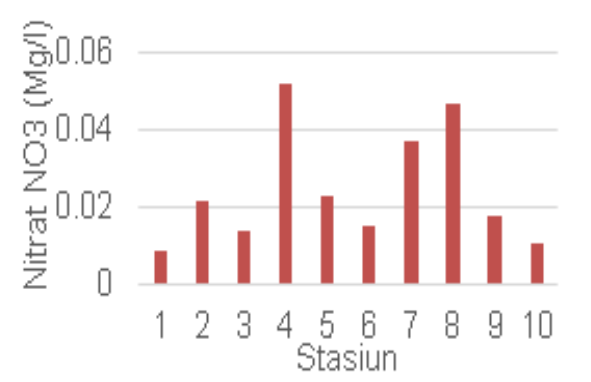

Gambar 9. Grafik Sebaran Nitrat di Lokasi Penelitian

Fosfat $(P)$

Hasil pengukuran fosfat yakni berkisar antara $0,017 \mathrm{mg} / \mathrm{l}-0,342 \mathrm{mg} / \mathrm{l}$. Meningkatnya senyawa fosfat dipengaruhi oleh asupan nutrien dari daerah tangkapan air, aktivitas penduduk sekitar pesisir dan kegiatan perikanan (Indrayani et al., 2015). Sumber utama fosfat di laut berasal dari sungai, penguraian sisa organisme dan pengadukan dasar laut [6].

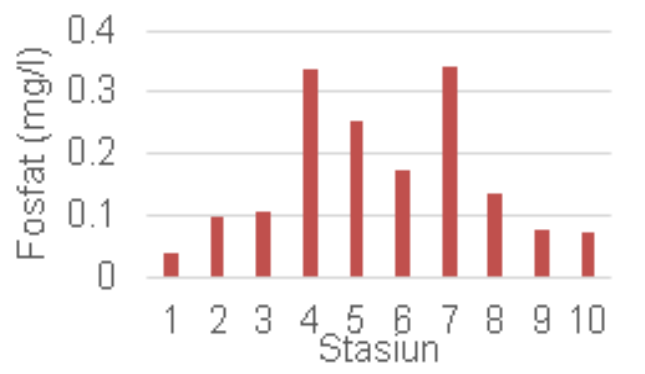

Gambar 10. Grafik Sebaran Fosfat di Lokasi Penelitian

\section{KESIMPULAN DAN SARAN}

\section{Kesimpulan}

1. Berdasarkan analisis klorofil-a di perairan Kecamatan Besuki dan Tanggung Gunung, sebaran klorofil-a tertinggi di wilayah area pelabuhan dan area pesisir yang terdapat keramba jaring apung yaitu $3,69 \mathrm{mg} / \mathrm{m}^{3}$ dan menurun diwilayah area yang lebih jauh yaitu $1,62 \mathrm{mg} / \mathrm{m}^{3}$ secara in situ atau tertinggi $1,31 \mathrm{mg} / \mathrm{m}^{3}$ dan menurun hingga $0.86 \mathrm{mg} / \mathrm{m}^{3}$ menurut data citra dengan keakuratan sebesar $46 \%$.

2. Berdasarkan hasil analisis tersebut dapat disimpulkan bahwa adanya pelabuhan serta keramba jaring apung membawa dampak eutrofikasi tertinggi pada kualitas air wilayah pesisir Kecamatan Besuki dan Tanggung Gunung, yang ditunjukkan dengan tingginya kandungan klorofil-a dan TSM perairan

\section{Saran}

Perlunya dilakukan monitoring perairan secara berkala berkaitan dengan dampak negatif yang ditimbulkan aktivitas manusia di wilayah pesisir. Secara ilmiah kondisi awan sangat berpengaruh terhadap nilai citra yang didapatkan sehingga penelitian perlu dilakukan pada saat cuaca baik. Pemilihan algoritma yang tepat serta akuisisi data citra pada waktu yang sama dengan pengukuran lapang sangat berpengaruh terhadap keakuratan data TSM dan Klorofil-a.

\section{DAFTAR PUSTAKA}

[1] Dahuri, R., Rais J., Ginting S.P., Sitepu, M.J. (cet. 2), 2001 : Pengelolaan Sumberdaya Wilayah Pesisir dan Lautan Secara Terpadu ; PT. Pradnya Paramita, Jakarta, Indonesia.

[2] Damar A. 2003. Effects Of Enrichment On Nutrient Dynamics, Phytoplankton Dynamics And Productivity In Indonesian Tropical Water: A Comparison Between Jakarta Bay, Lampung Bay And Semangka Bay. [Disertation]. Kiel (De): Cristian Albert University.

[3] Effendi, H. 2003. Telaah Kualitas Air Bagi Pengelolaan Sumberdaya Dan Lingkungan Perairan. Kanisius. Yogyakarta 
[4] Fabianto, M. D. Dan P. T. Berhitu. 2014. Konsep Pengelolaan Wilayah Pesisir Secara Terpadu 2055 Dan Berkelanjutan Yang Berbasis Masyarakat. Jurnal Teknologi. 11(2): $2054-2058$.

[5] Fachrul, M., Haeruman, H., Sitepu, L.C. 2005. Komunitas Fitoplankton Sebagai Bioindikator Kualitas Perairan Teluk Jakarta. Seminar Nasional Mipa 2005. Fmipauniversitas Indonesia, 24-26 November 2005. Jakarta.

[6] Faturohman, I., Sunarto dan I. Nurruhwati. 2016. Korelasi Kelimpahan Plankton Dengan Suhu Perairan Laut Di Sekitar Pltu Cirebon. Jurnal Perikanan Kelautan. 7(1): 115-122.

[7] Fransisca, A., 2011. Tingkat Pencemaran Perairan Ditinjau dari Pemanfaatan Ruang di Wilayah Pesisir Kota Cilegon. Jurnal Perencanaan Wilayah dan Kota. 22(2):145-160

[8] Gultom, J., B. Amin, Y. Ikhwan.2011. Kandungan Logam Berat Timbal $(\mathrm{Pb})$ dan Tembaga $(\mathrm{Cu})$ Pada Air Laut dan Sedimen di Perairan Batubara Provinsi Sumatera Utara. Jurnal CWNS Provinsi.

[9] Lillesand, T. M. And Kiefer. 1990. Penginderaan Jauh Dan Interpretasi Citra. Alih Bahasa: Dulbahri, P., Suharsono, Hartono, Suharyadi. Gajah Mada University Press: Yogyakarta. 725 Hal

[10] Marendy, F., Hartoni, Dan Isnaini. 2017. Analisis Pola Sebaran Konsentrasi Klorofil-A Menggunakan Citra Satelit Landsat Pada Musim Timur Di Perairan Sekitar Muara Sungai Lumpur
Kabupaten Oki Provinsi Sumatera Selatan.” Maspari Journal. 9(1):33-42.

[11] Marlian, N., A. Damar Dan H. Effendi. 2015. Distribusi Horizontal Klorofil-A Fitoplankton Sebagai Indikator Tingkat Kesuburan Perairan Di Teluk Meulaboh Aceh Barat. Jurnal Ilmu Pertanian Indonesia (Jipi). 20 (3): 272-279.

[12] Nuriya, H., Z. Hidayah Dan W. A. Nugraha. 2010. Pengukuran Konsentrasi Klorofil-A Dengan Pengolahan Citra Landsat Etm-7 Dan Uji Laboratorium Di Perairan Selat Madura Bagian Barat. Jurnal Kelautan. 3 (1): 60-65

[13] Refi, A. 2013. Analisis Break Water Pada Pelabuhan Teluk Bayur Dengan Menggunakan Batu Alam, Tetrapod, Dan A-Jack. Jurnal Momentum. 15(2): 1-14

[14] Susana, T. 2005. Kualitas Zat Hara Perairan Teluk Lada, Banten. Oseanologi Dan Limnologi Di Indonesia : 59-67.

[15] Susiati H., E. Kusratmoko Dan A. Poniman. 2010. Pola Sebaran Sedimen Tersuspensi Melalui Pendekatan Penginderaan Jauh Di Perairan Pesisir Semenanjung Muria-Jepara. Jurnal Teknologi Pengelolaan Limbah (Journal of Waste Management Technology. 13(1).

[16] Susilo, S. B. 2000. Penginderaan Jauh Kelautan Terapan. Penerbit Institut Pertanian Bogor. Bogor 